\begin{tabular}{|l|l|l||}
\hline \multicolumn{2}{|c|}{ PublisherInfo } \\
\hline \hline PublisherName & $:$ & BioMed Central \\
\hline \hline PublisherLocation & $:$ & London \\
\hline \hline PublisherImprintName & $:$ & BioMed Central \\
\hline \hline
\end{tabular}

\title{
Digital Breast Clinic
}

\begin{tabular}{|l|l|l||}
\hline \multicolumn{2}{|c|}{ ArticleInfo } \\
\hline \hline ArticleID & $:$ & 3670 \\
\hline \hline ArticleDOI & $:$ & $10.1186 /$ bcr-2000-2-webreport0002 \\
\hline \hline ArticleCitationID & $:$ & 0002 \\
\hline \hline ArticleSequenceNumber & $:$ & 36 \\
\hline \hline ArticleCategory & $:$ & Web Report \\
\hline \hline ArticleFirstPage & $:$ & 1 \\
\hline \hline ArticleLastPage & $:$ & 3 \\
\hline \hline & & RegistrationDate : 2000-1-31 \\
ArticleHistory & $:$ & OnlineDate $\quad$ 2000-1-31 \\
\hline \hline ArticleCopyright & $:$ & Current Science Ltd2000 \\
\hline \hline ArticleGrants & $:$ & \\
\hline \hline ArticleContext & $:$ & 1305822 \\
\hline \hline
\end{tabular}




\section{Content}

Newly established website which is maintained by Dr Hadi Yaziji based in Seattle, USA.

The website serves as an educational tool for breast cancer specialists, but also acts as a forum to integrate the latest scientific developments in breast cancer research.

The home page allows access to the 'Editor's notes' describing a clinical breast cancer 'Case Study' which is updated weekly. The 'Guests' Corner' provides extensive information about new therapeutic agents for breast cancer; it includes a synopsis on the HER-2 oncogene and discusses the use of Herceptin as a putative treatment. In addition, this section contains a discussion about breast biopsies written by an international expert in the breast pathology field. The 'Introduction to...' section describes Nuclear Breast Imaging technologies, and digitized mammograms and photomicrographs are displayed. 'Information pages' presents a fully illustrated breast cancer classification guide. Topical issues are found within 'Timely Debates' which currently features a discussion on the detection of the oncogene HER-2, and includes a survey which encourages interactive communication between scientists.

\section{Navigation}

This well organised site is simple to navigate, and all pages contain a 'back to' link. The site is fully searchable but presently does not contain useful links to other sites. However, plans are currently in progress to include other links.

\section{Timeliness}

Dr Yaziji has informed the reporter that the site is updated every two weeks and a significant update is scheduled within the next month, although this information is not displayed. Registration is not required for this site, and there is an opportunity to contact the editor.

\section{Evaluation}


Digital Breast Clinic serves as a forum for all aspects of breast cancer research, with particular emphasis on the pathology and clinical aspects of malignant breast disease. This site offers the potential for collaborative diagnostic work for the scientific community and enhances knowledge within this specialist field. An interesting feature, 'Case of the week', uses multidisciplinary approaches to assess the latest developments. Overall this informative site provides an invaluable facility for breast cancer researchers and scientists.

\section{References}

1. The Digital Breast Clinic. [http://www.digitalclinic.com/index.htm] 